\title{
Designation, Implementation and Evaluation of Activities to Ensure Transition from Arithmetic to Algebra
}

\author{
Ramazan GÜRBÜZ ${ }^{1, *} \&$ Zehra TOPRAK ${ }^{2}$ \\ ${ }^{1}$ Adıyaman University, Adıyaman, TURKEY; ${ }^{2}$ Ministry of Education, \\ Gaziantep, TURKEY;
}

Received: 06.03.2013

Accepted: 31.01 .2014

\begin{abstract}
Maths teaching through activities help students learn maths which is abstract in a concrete environment in which students feel comfortable. Concretization of transition from arithmetic that students are already familiar with to algebra that they will experience for the first time through activities is getting more and more important. This study aims to design, implement and assess activities that will ensure 7th grade students' transition from arithmetic to algebra. The study, which is in a semi-experimental design, is carried out with 58 $7^{\text {th }}$ grade students, 30 of them being in experimental group and 28 in control group. A lateral equation test consisting of 10 open-ended questions was given to students in the study before and after the implementation. Independent sampling t-test was used in the analysis of the data collected. As a result of the analysis, it was found out that activity-based teaching is more effective in teaching equations than traditional teaching method.
\end{abstract}

Key words: Transition from arithmetic to algebra, activities, equations, 7th grade students.

DOI No: 10.12973/nefmed.2014.8.1.a8

\section{Summary}

\section{Introduction}

Recent developments in maths teaching focus on activities that help students find their own formulas and rules and also construct basic concepts by themselves instead of memorizing maths formulas or rules. Within that context, activity-based maths teaching is gaining importance. Presentation of maths formulas to primary school students in a concrete

\footnotetext{
* Corresponding author: Ramazan GÜRBÜZ, Assoc. Prof. Dr., Department of Primary Maths Education, Faculty of Education, Adiyaman University, Adiyaman, TURKEY.

E-mail: rgurbuz@adiyaman.edu.tr,rgurbuz@outlook.com

Note: This study is a condensed version of master thesis by Zehra Toprak.
} 
way will facilitate meaningful learning and learning of complex maths concepts (Gürbüz \& Akkan, 2008). Transition from arithmetic to algebra is a difficult process for students. When transition from arithmetic to algebra is carried out in a proper way, students are observed to be more successful in learning the variable concept (Arcavi \& Schoenfeld, 1988, Ursini \& Trigueros, 2001), learning algebraic verbal problems (Kieran, 1991; Lodholz, 1993; Linchevski, 1995), learning equations concept and finding the solution set of equations (Hersovics \& Linchevski, 1994; MacGragor \& Stacey, 1997). It is assumed that transition to this process through activities will ensure students internalize knowledge and will also guide students in learning future abstract algebra subjects.

\section{Methodology}

"Research design with pre-test - post-test control group" was used in the study. Thus, while activity-based teaching was carried out in the experiment group, traditional teaching methods were followed in the control group. The study was conducted with $587^{\text {th }}$ graders studying in a state school in Gaziantep with 30 of them being in experimental group and 28 in control group. A test consisting of 10 open-ended questions was used as data collection tool. It included 7 questions which were taken from Akkan (2009), 1 question taken from a formal exam administered by National Ministry of Education and 2 questions prepared by the researchers with the help of expert opinions.

\section{Results}

The difference between averages of posttest scores of the experiment group and those of the control group were compared with t-test and the difference was found to be significant at $\mathrm{p}<.05$ significance level. Based on these data, the experimental group was found to be more successful than the control group based on comparison of both groups' success in the posttesst. Similarly, when correlation rates of both groups were analyzed from the pretest to posttest, it was found out that students in the experimental group achieved better results than their counterparts in the pretest.

\section{Discussion}

Results illustrate that activity-based maths teaching yielded more positive results in terms of transition from arithmetic to algebra. This finding is consistent with Özlü (2001) who also found out that students would become more successful and show more positive 
attitudes towards maths learning in classroom environments where they are kept more active. This study showed that activities facilitate students' learning of algebraic expressions.

Data also showed that $7^{\text {th }}$ graders' use of solutions involving prealgebraic features, which is one of the aritmethic solution strategies, has a role in their achievement from pre-test to post-test. Linchevski (1995) and Akkan (2009) reached similar results in that sense.

Students took part in class more actively during acitivity-based maths teaching and they interact with their peers and teachers through concrete materials. Activity-based teaching necessitates teaching through use of various teaching tools and concrete materials. Such materials are of high importance in that they keep students' attention on the task, concretize maths that is abstract enough and help students understand that maths has a real value in real life and it has real uses. Though it necessitates preparation and researches on part of teacher, activity-based teachings is significant in terms of helping students like and learn maths which is regarded as a nightmare by many students in Turkey. This study has revealed that activitybased teaching increases student success. Also, it increases class participation and teacher's classroom management.

\section{Conclusion}

This study has shown that activity-based maths teaching facilitates student learning of simple equations and that such a teaching facilitates transition from arithmetic to algebra. Constructivist curriculum approach that has been implemented since 2004 in Turkey supports activity-based teaching. This study has come up with findings that support concepts such as learning by doing, constructing knowledge rather than rote-memorization that are supported by constructivist approach. Within that framework, it has also supported the finding that constructivist approach that depends on activity-based teaching creates an added-value.

Although activity-based teaching seems to display some shortcomings such as necessitating some time of preparation by teacher, it could be maintained that it has very important characteristics that help students transition from aritmetic to algebra and that enable students to learn maths through concrete materials. Some studies (Özmantar, Bozkurt, Demir, Bingölbali \& Açı1, 2010) revealed that teachers have limited perceptions towards activity concept and that teachers' training related to use of activity-based approach is needed, thus, all resources must be utilized to help this approach implemented effectively as every single approach that can create positive changes in students' learning must be supported. 


\title{
Aritmetikten Cebire Geçişi Sağlayacak Etkinliklerin Tasarlanması, Uygulanması ve Değerlendirilmesi
}

\author{
Ramazan GÜRBÜZ ${ }^{1,+}$ \& Zehra TOPRAK ${ }^{2}$
}

\author{
${ }^{1}$ Adıyaman Üniversitesi, Adıyaman, TÜRKİYE; ${ }^{2}$ Milli Eğitim Bakanlığı, \\ Gaziantep, TÜRKİYE
}

Makale Gönderme Tarihi: 06.03.2013

Makale Kabul Tarihi: 31.01.2014

\begin{abstract}
Özet- Etkinliklerle matematik öğretimi, öğrencinin kendini daha güvende hissettiği somut bir ortamda öğrenmesine yardımcı olmaktadır. Soyut olan matematik bilgisini öğrencilere doğrudan aktarmak yerine etkinlik temelli vermenin daha etkili olacağı düşünülmektedir. Bu sebeple öğrencilerin aritmetikten cebire geçişlerini etkinlikler yoluyla somutlaştırabilmek önem arzetmektedir. Bu araştırmanın amacı; 7. sınıf öğrencilerinin denklemler konusunda aritmetikten cebire geçişlerini sağlayacak etkinlikleri tasarlamak, uygulamak ve değerlendirmektir. Yarı deneysel yöntemle yürütülen araştırma, 30’u deney, 28’i kontrol grubu olmak üzere toplam 58 7. sınıf öğrencisiyle gerçekleştirilmiştir. Çalışma grubundaki öğrencilere, 10 açık uçlu sorudan oluşan birinci dereceden bir bilinmeyenli denklemler testi işlem öncesi ve sonrası uygulanmıştır. Verilerin analizinde, bağımsız örneklem t-testi kullanılmıştır. Yapılan analizler sonucunda, etkinlik temelli öğretimin geleneksel öğretime göre, denklemler konusunun öğretiminde daha etkili olduğu belirlenmiştir.
\end{abstract}

Anahtar Kelimeler: Aritmetikten cebire geçis, etkinlikler, denklemler, 7. sinıf öğrencileri

DOI No: 10.12973/nefmed.2014.8.1.a8

\section{Giriş}

Son yıllarda matematik eğitimindeki gelişmeler, öğrencilere matematik formülü ya da kuralı ezberletmek yerine onların bu formül ve kuralları kendilerinin bulmasına ve temel kavramları kendilerinin oluşturabilmelerine olanak sağlayacak etkinliklere vurgu yapmaktadır. $\mathrm{Bu}$ bağlamda, etkinlik temelli matematik öğretimi ön plana çıkmaktadır. Suydam ve Higgins (1977)'e göre etkinlik temelli öğretimin en önemli özelliği öğrencinin sürece aktif olarak katılmasıdır. Bu katılım hem zihinsel hem de bedensel olarak öğrenciyi

\footnotetext{
† İletişim: Doç. Dr. Ramazan GÜRBÜZ, İlköğretim Matematik Eğitimi Bölümü, Adıyaman Eğitim Fakültesi, Adıyaman Üniversitesi, Adıyaman, TÜRKIYYE.

E-posta: : rgurbuz@adiyaman.edu.tr,rgurbuz@outlook.com
}

Not: Bu çalışma Zehra TOPRAK'ın yüksek lisans tezinin kısaltılmış halidir. 
aktif kılmaktadır. Çünkü bu süreçte öğrenci etkinliği ya yaparak ya da etkinlik yapılırken sürece müdahil olarak aktif bir katılım sergilemektedir.

Ainsworth (2006)'e göre matematik öğretimi daha özel öğretim/öğrenme teknik ve stratejilerinin kullanımını gerektirir; çünkü belli kavram ve metotları öğrenmek değişik bilimsel temsilleri anlama ve kavramayı kapsamaktadır. Tytler (2003), bu öğretim/öğrenme tekniklerinin öğretmen tarafından verilecek olan açıklayıcı fikirler ve ipuçları ile öğrenciyi aktif tutacak özelliklere sahip olması gerektiğini dile getirmektedir. $\mathrm{Bu}$ tekniklerle öğrencilerin matematik kavramlarını yaşadıkları dünyadaki pratikler ve gerçek amaçlarla ilişkilendirmeleri sağlanmış olur. Piaget'ye göre fiziksel bilgiler gözleme veya deneye dayalı soyutlamalarla oluşturulurken, matematiksel bilgiler düşünmeye dayalı soyutlamalarla yapılandırılırlar. Ancak küçük yaştaki çocuklar için bu iki bilgi türü birbirinden çok da bağımsız değildir ve pek çok soyut matematik kavramının anlaşılmasında fiziksel bilgi önemli bir rol oynar (Tunç, Durmuş \& Akkaya, 2012). Dolayısıyla, öğrencilerin daha soyut olan cebir bilgisini kavramaları için fiziksel yaşantı içinde bulunmaları aritmetikten cebire geçişi kolaylaştırabilmektedir.

Matematik kavramlarının küçük yaşlarda(ilköğretim birinci ve ikinci kademede) öğrencilere olabildiğince somutlaştırılmış bir şekilde verilmesi, hem anlamlı öğrenmenin gerçekleşmesini, hem de ileri matematik kavramlarının öğrenilmesini kolaylaştıracaktır (Gürbüz \& Akkan, 2008). Farklı doğalara sahip olmalarına karşın, aritmetik ile cebir arasında kuvvetli bir bağ vardır (Akkan, Baki \& Çakıroğlu, 2011; Kieran, 1992; Van Amerom, 2002). Karşılaştırma, sayma ve sayılarla işlem yapma eylemlerini içeren aritmetiğin soyutlanmasıyla matematiğin önemli bir dalı olan cebir doğmuştur (Akgün, 2006; Akkan 2009). Bundan dolayı öğrenciler cebirle ilgili fikirlerini aritmetikle ilgili daha önceki deneyimlerinden yola çıkarak yapılandırırlar (Booth, 1988; Herscovics \& Linchevski, 1994; Gürbüz \& Akkan, 2008; Kieran, 1992). Bu yapılandırma süreci ara geçiş olarak cebir öncesi (pre-cebir) kavramına denk gelmektedir. Aritmetikle cebir arasında köprü vazifesi gören cebir öncesi kavramı, öğrencilerin mevcut aritmetik ve geometrik bilgilerini kullanmalarına imkan tanıyarak cebirsel kavramları ve prosedürleri informal olarak anlamlandırmalarına firsatlar sağlayabilmesi sürecidir (Akkan, 2009; Kieran \& Chaloug, 1993). Genel olarak bakıldığında, ilköğretim birinci kademe müfredatı somut, ortaöğretim seviyesindeki matematik müfredatı ise soyuttur ve ilköğretim ikinci kademe müfredatında, aritmetikten cebire geçiş bir köprü vazifesi görmektedir (Akkan 2009; NCTM, 1989).

Herscovics ve Kieran (1980) öğrencilerin sembolleri yetişkinlerden farklı bir şekilde yorumladıklarını, aritmetik özdeşliklerden denklemleri inşa ettiklerini belirterek, cebirdeki bir 
denklem ile aritmetikteki bir denklemin farklılığının ortaya konması gerektiğini söylemişlerdir (Dede, 2005). Cebir genelikle çeşitli semboller, ifadeler ve gösterimler yardımıyla denklem çözümlerinin bulunması olarak algılanır ve denklem ve denklem çözümlerinin bulunması cebirin temelini teşkil etmektedir. Linchevski (1995), okul cebirinin beş ana bileşenini tanımlamış (değişkenler ve cebirsel ifadeleri sadeleştirme, genelleştirme, yapı, denklemler, sözel problemler) ve bu beş bileşenin cebir öncesi etkinliklerle geliştirilmesinin, daha sonraki cebir öğretimi için hayati önem taşıdığına vurgu yapmış ve cebir öncesini bu beş bileşeni destekleyecek ön kavramların inşa edildiği alan olarak tanımlamıştır.

Öğrencilerin aritmetikten cebire geçiş süreçleri sıkıntılı bir süreçtir. Özellikle denklem konusuyla ilgili bu geçiş sürecindeki sıkıntının birçok nedeni olabilir. Örneğin; sözel problemleri denklemlere dönüştürmedeki zorluklar (Bernardo \& Okagaki, 1994; Filloy \& Rojano, 1989; Linchevski \& Hersovics, 1996), harfleri veya çeşitli gösterim şekillerini matematiksel anlamlandırmadaki zorluklar (Kieran 1989, 1992), aritmetiksel kurallardan cebirsel kurallara geçişteki zorluklar, eşitlik ve değişken kavramının anlaşılmasındaki zorluklar (Usiskin, 1988; Falkner, K., Levi, L. \& Carpenter, T., 1999) bu sebeplerden bazılarıdır. Herscovics ve Linchevski (1994) öğrencilerin aritmetikle cebir arasında yaşadığı bu zorlukların bilişsel bir boşlukla, yani öğrencilerin bilinmeyenleri kullanarak yaptığı işlemlerdeki yeteneksizliğiyle bağlantılı olduğunu dile getirmiştir. Bu boşluğun üstesinden gelmede cebir öncesi evrenin önemine dikkat çeken çok sayıda araştırma mevcuttur (Filloy \& Rojano, 1989; Kieran, 1992; Londholz, 1993; Kieran \& Chalouh, 1993; Hersovics \& Linchevski, 1994; Linchevski, 1995; Van Amerom, 2002).

Aritmetikten cebire geçişin tam olarak sağlanması durumunda, öğrencilerin değişken ve denklem kavramını anlamada (Arcavi \& Schaenfeld, 1988, Ursini \& Trigueros, 2001), denklemlerin çözüm kümelerini bulabilmede (Hersovics \& Linchevski, 1994; MacGragor \& Stacey, 1997) ve cebirsel sözel problemleri öğrenmede (Kieran, 1991; Londholz, 1993, Linchevski, 1995) daha başarılı oldukları görülmüştür. Bu geçişin, etkinlikler yardımıyla başarılı bir şekilde gerçekleştirilmesinin öğrencilerin bilgiyi içselleştirmelerini sağlayacağ 1 ve ileriki soyut cebir konularını da başarılı bir şekilde öğrenmelerine kılavuzluk edeceği düşünülmektedir.

Ülkemizde aritmetikten cebire geçiş sürecinde yurtdışındaki sorunlara benzer olarak; problemi anlamama, sözel problemleri matematik diline çevirememe, verilen sözel probleme ilişsin uygun denklem kuramama, denklem kurma aşamasından sonra yapılan işlemsel hatalar nedeniyle denklemi sadeleştirememe ve sonuca ulaşamama gibi sorunlar vardır. Bunların 
yanısıra denk terimleri tanımada ve benzer terimleri birleştirmede; bir terimi eşitliğin diğer tarafına geçirirken işaretini değiştirmeden karşı tarafa geçirmede; sadeleştirme ve genişletme işlemini sadece eşitliğin bir tarafına uygulamada; her iki tarafı aynı sayıya bölerken bölümü ters çevirmede; toplamayı ve çarpmayı yanlış ayırmada; kesirleri sadeleştirmede ve paranteze almada; negatif katsayılı ifadelerle işlem yaparken eksi işaretini kullanmada; aritmetiğin temel kavramı olan sayı kavramıyla ilgili işlemlerde öğrencilerin ortak hata ve yanılgılara sahip oldukları belirtilmiştir (Akkan, 2009; Linchevski \& Herscovics, 1996; Cortes \& Pfaff, 2000; Lee, 2002; Dede, Yalın ve Argün, 2002; Van Dooren, Verschafel ve Onghena, 2003; Vlasis, 2004; Dede \& Peker, 2007). Genelleme yapma sürecinde örüntü ve dört işlem özelliklerinde (değişme özelliği, birleşme özelliği gibi), sembollerin kullanımı sürecinde (eşittir işareti, parantez kullanımı vb.), harfleri anlamlandırma sürecinde (nesne, bilinmeyen, değişken vb.) de zorluklarla karşılaşılmaktadır (Akkan, 2009).

2005 'te öğretim programlarında köklü değişiklikler yapılmasına rağmen, öğretmenler tarafından sürece dayalı öğrenme biçimlerinin ve öğretmenin daha çok rehberlik rolünü üstlendiği öğrenci merkezli öğretim yöntemlerinin yeterince uygulanamadığı bilinmektedir (Memnun, 2008; Gürbüz, 2008). Ülkemizde aritmetikten cebire geçişte öğrencilerin yaşadıkları zorlukların nedenleri arasında geleneksel öğretim metotlarının halen uygulanıyor olmasının da etkili olduğu söylenebilir. Öğrencilerin, tüm hayatları boyunca kullanacakları cebirsel yapıları daha iyi anlamaları için aritmetikten cebire geçişte uygulanan öğretimin doğasının değişmesi, öğretimin etkinlik temelli hale getirilmesi ve öğrencinin somut materyallerle öğrenmeyi içselleştirmesi gerekmektedir. Öğrenciler günlük yaşantılarında matematiği kullanmalı ve matematiğe karşı olumlu tutum geliştirmelidirler (MEB, 2009). Öğrenciler kendi beğenilerine ve düzeylerine uygun etkinliklerle tasarlanmış, öğrenirken eğlenebilecekleri, deneyim yaşayabilecekleri, bilgiye kendilerinin ulaşmasına olanak sağlayan öğrenme ortamlarında matematiğin soyutluğundan uzaklaşarak ve matematiği birebir yaşayarak matematiğe karşı olumlu tutum geliştirebilirler.

Öğrenme ortamlarında etkinliklerin kullanımı; öğrenciyi merkeze almakta, daha zengin öğrenme firsatları sunmakta, matematikle ilgilenmeyi ve matematiği sevmeyi sağlamakta, matematik öğretimini eğlenceli hale getirmekte, matematiğin yazılmasına ve tartışılmasına fırsat vermekte ve öğrenci motivasyonlarının artmasını sağlamaktadır. Buna paralel olarak, Özgenç (2010), oyun temelli etkinliklerin öğrenci ilgisini ve katılımını arttırdı̆̆ı, Cüce (2012) öğrenci ilgi, alg1 ve ihtiyaçlarına uygun tasarlanan sınıf ortamlarının dersleri daha eğlenceli hale getirdiği, Gürbüz (2008) ise, matematik öğretiminde orijinal, eğlenceli ve günlük yaşamı temsil eden öğretim araçlarının kullanılmasının, öğrencilerin 
matematik algılarını olumlu etkilediği yönünde bulgulara ulaşmışlardır. $\mathrm{Bu}$ çalışmayla, ilköğretim 7. sınıf öğrencilerinin aritmetikten cebire geçişlerini sağlayacak etkinlikleri tasarlamak, uygulamak ve değerlendirmek amaçlanmıştır.

\section{Yöntem}

Araştırmada deneysel araştırma yöntemlerinden “öntest-sontest kontrol gruplu araştırma yöntemi” kullanılmıştır. Bu kapsamda deney grubunda etkinlik temelli öğretim, kontrol grubunda ise öğretmen merkezli öğretim uygulanmıştır. Öğretmen merkezli öğretim uygulanırken ders kitabı takip edilmiş, kitap içerisindeki etkinlikler göz ardı edilerek düz anlatım yöntemiyle ders işlenmiş, bilgiler hazır olarak öğrencilere sunulduktan sonra alıştırmalara yer verilmiştir. Bu araştırmada iki probleme cevap aranmıştır. Bunlar;

İlkögretim 7. sınıfta 1. dereceden denklemler konusunu etkinlik temelli öğrenme ortamında öğrenen öğrencilerin başarıları ile öğretmen merkezli öğrenme ortamında öğrenen öğrencilerin başarıları arasında istatistiksel olarak anlamlı bir fark var mıdır?

Etkinlik temelli öğretim stratejisiyle öğretmen merkezli öğretim stratejisinin ilköğretim 7. sınıf öğrencilerinin 1. dereceden denklemler konusundaki problemlerini giderme yüzdeleri arasında anlamlı bir fark var midir?

\section{Çalışma Grubu}

Bu araştırma, 2010-2011 öğretim yılında, Güneydoğu Anadolu Bölgesinde, resmi bir ilköğretim okuluna devam etmekte olan 30’u deney grubu, 28'i kontrol grubunda olmak üzere toplam 58 yedinci sınıf öğrencisinin katılımı ile gerçekleştirilmiştir. Araştırmacı öğretmen, bir 6. sınıfın ve iki 7. sınıfın matematik derslerini yürüttügünden, deney ve kontrol grubu olarak 7. sınıftaki iki şubeyi seçmiştir. Ayrıca, araştırmacı öğretmen 8. sınıf seviyesinde iki şubeye girmektedir fakat bu çalışma, etkinlik temelli öğretimin denklemler konusunun öğrenilmesine etkisini incelemeyi amaçladığından ve 8. sınıf seviyesinde daha ileri denklemler konusu işlendiğinden, 7. sınıf seviyesinde derslerine girdiği iki sınıftan biri deney diğeri kontrol grubu olarak rastgele seçilmiştir. Araştırmacılardan biri, araştırmayı bizzat öğretmenlik yaptığg okulda gerçekleştirmiş olup, dersleri kendisi yürütmüştür.

\section{Veri Toplama Arac1}

Bu çalışmada, veri toplama aracı olarak, Akkan (2009)'dan alınan, yapı ve kapsam geçerliği yapılmış 7 açık uçlu soru, aynı şekilde MEB tarafından düzenlenen merkezi bir 
sınavdan alınan geçerliği sağlanmış 1 soru kullanılmıştır. Ayrıca, araştırmacılar ilköğretim matematik eğitimi alanında uzman iki akademisyenden görüş alarak 2 soru hazırlamışlardır ve bu soruların kapsam, dil, öğrenci seviyelerine uygunluğu açısından geçerliklerini sağlamışlardır. Buna ek olarak, aynı okulda görevli bir matematik öğretmeninin de görüşü alınmıştır. Böylece, toplam 10 açık uçlu sorudan oluşan bir test kullanılmıştır.

\section{Etkinliklerin Tasarlanması}

Bilginin aktif olarak birey tarafından kurulduğu bir yaklaşım olan yapısalcılık, öğrencinin konu hakkındaki kendi anlayışını oluşturmasına izin verilecek şekilde eğitilmesini öngören bir yaklaşımdır. Bu yaklaşımda, öğrenme aktif bir süreç olup, dayatılamaz (Güngör, 2005; Yanpar, 2001). Bilginin öğrenciye sunulması yerine, öğrencinin bilgiye ulaşmasının daha değerli olduğu ve kalıcı öğrenmelerin daha kolay gerçekleşeceği (Aygün vd., 2011) düşünüldüğünde, öğrencilerin ilgilerini çekecek ve bilgiyi kendilerinin yapılandıracağ1 etkinliklerin tasarlanması matematik dersi ile ilgili öğrenci algılarında olumlu etkide bulunacaktır. Etkinliklerle zenginleştirilmiş eğitsel ortamlar bireylerin zihinlerinde daha önce yapılandırdıkları bilgilerin doğruluğunu sınar, yanlışlarını düzeltir ve bireyler önceki bilgilerden vazgeçerek yerine yenisini koyma fırsatı elde ederler (Cüce, 2012; Yaşar, 1998; Akar, 2006).

Etkinlik tasarlama süreci kolay bir süreç olmayıp çok farklı aşamaları içermektedir (Healy, Fernandes ve Frant, 2013, s. 66) ve bu süreçte çok farklı değişkenlerin göz önünde bulundurulması gerekmektedir. Bu değişkenlerin başında etkinliğin amacı, sınıf yönetimi, etkinliğin birden fazla başlangıç noktasına sahip olması, kullanılacak araçlar, uygulama esnasında öğrenci ve öğretmen rolleri (Bingölbali \& Özmantar, 2012) gelmektedir. Etkinlik tasarlamaya başlamadan önce, etkinliğin hangi kazanımları edindirmeyi amaçladığı, mevcut bilgiyi güçlendirme veya yeni bilgiyi sunma hedeflerinden hangisini gerçekleştirmeyi amaçladığı göz önüne alınmalıdır. Amacı, planlanan etkinliğin uygulanacağı sınıfın örgütlenme şekli, sınıftaki öğrenci sayısı ve etkinliğe ayrılacak zaman da etkinlik tasarlanma sürecini şekillendirmektedir. Uygulanacak sınıfın mevcudu, zaman sınırlılığı gibi faktörler hem öğrenci hem öğretmen rollerini etkileyebilmektedir. Bu kapsamda, amaca ek olarak uygulanabilirlik prensibine de dikkat etmek gerekmektedir (Kerpiç \& Bozkurt, 2011; Ainley, Pratt \& Hansen, 2006). Sınıf dinamikleri etkinliklerin planlanandan farklı şekilde uygulanmasını gerektirebileceğinden etkinlik fizibilitesini optimum şartlara göre esnekleştirebilmek (Dündar \& Şenol, 2011) göz önüne alınması gereken bir başka faktör olarak ortaya çıkmaktadır. Nitekim, öğrencinin aktif, öğretmenin de rehber olması beklenen 
etkinlik temelli matematik eğitiminde (Özmantar, Bozkurt, Demir, Bingölbali \& Aç1l, 2010; Doyle, 1988), etkinliklerin uygulanması ile ilgili sınıfsal değişkenler bu beklentiyi olumsuza dönüştürebilmektedir. Ayrıca, sınıfların farklı ilgi ve kabiliyetlerde öğrencilerden oluşabileceği göz önüne alındığında, etkinliklerin her seviyeden öğrencinin sürece dahil olup uğraş göstermesine firsat vermesi ve çok farklı türden materyal kullanılması beklenmektedir (Bingölbali \& Özmantar, 2012).

Mevcut araştırmadaki etkinliklerin tasarlanmasında, MEB (2009) kitabındaki kazanımlar göz önüne alınmış ve etkinlik tasarlama sürecinde ilgili literatürde belirlenen öncelikler dikkate alınarak hazırlanmıştır. Araştırmacı etkinliklerin uygulanması sürecine araştırmacı-uygulamacı olarak katılmış ve aktif olarak öğretmenlik yaptığı 30 öğrenciden oluşan deney grubuna zaman baskısı hissedilmeden etkinliklere tüm öğrencilerin aktif katılımlarının sağlanabileceğini düşünerek etkinlikleri tasarlamıştır.

Araştırmacılar, öğrencilerin bilgiyi kendilerinin yapılandıracakları, öğrenirken eğlenecekleri ve öğrenmeyi günlük hayatla ilişkilendirmelerini sağlayacak etkinlikler tasarlamışlardır. Hazırlanan etkinlikler haftada 4 saat olmak üzere 4 haftada 16 ders saatini kapsayacak şekilde tasarlanmıştır.

Etkinliklerde öğrenmeyi kolaylaştıracak materyaller (eşit kollu terazi, ağırlık takımı, köpük pano, sayma pulları, ağırlıkları ölçülecek paket süt, çikolata vb. nesneler) kullanılmıştır. Özellikle eşitlik kavramı ve eşittir işaretinin daha iyi anlaşılabilmesi için sınıfa eşit kollu terazi götürülmüş ve dengenin, eşitliğin bir modeli olduğu sezdirilmeye çalışılmıştır. Etkinlikler kullanılarak öğrencilerin cebirsel işlemleri yaşayarak yapmalarına yardım edilmiştir. Son aşamada ise, öğrencilerin uygulamasını yaptıkları işi tamamen cebirsel dile çevirmeleri sağlanarak kavramları soyutlamaları amaçlanmıştır.

Kazanımlar 1. Eşitliğin korunumunu modelle gösterir ve açılar.

2. Birinci dereceden bir bilinmeyenli denklemleri çözer.

3. Denklemi problem çözmede kullanır. (MEB, 2009).

Beceriler : Problem çözme, akıl yürütme, ilişsilendirme.

Yöntem ve Teknikler: Sorgulama ve keşfetme, grup çalışması, gösterip yaptırma, tartışma.

Dikkat Çekme: Pazardaki satıcılar niçin terazi kullanır? Pazardan alış veriş yapıldıktan sonra alınanların nasıl taşındığına hiç dikkat ettiniz mi? 


\section{Etkinlik 1}

Sınıfa terazi getirilir (Şekil 1). Sınıfa getirilen terazinin sol kefesine paket sütler konur. Sağ tarafına da bunu dengeleyecek ağırlık konur. Denklem yazdırılır. Denklemde kullanılan eşittir işaretinin dengeyi belirttiği vurgulanır. Denge kurulduktan sonra bir paket süt sol kefeden alınır. Dengenin korunup korunmadığı sorulur. Dengeyi korumak için ne yapılması gerektiği sorulur. $\mathrm{Bu}$ şekilde, öğrencilerin eşittir işaretinin sol tarafında çıkarma işlemi yapılıyorsa sağ tarafında da aynı işlemin yapılarak dengenin korunabileceği sezdirilir (Toplama işlemi de aynı şekilde vurgulanır).

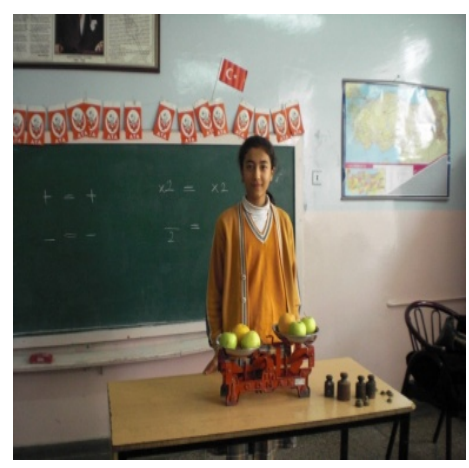

Şekil 1. Denge Modellemesi için Kullanılan Terazi

Sol kefeye önceden hazırlanan bir ağırlık ikiye bölünüp konur. Sağ kefeye de bunu dengeleyecek bir ağırlık konur. Öğrencilerden, sol kefeye konan cismin bölünmeden önceki ağırlığını bulmaları istenir. Böylece eşittir işaretinin solunda çarpma işlemi gerçekleştiriliyorsa sağında da aynı işlemin gerçekleştirilmesi gerektiği sezdirilir (Bölme işlemi de aynı şekilde vurgulanır).

Terazinin hiçbir kefesinde ağırlık yokken terazi dengededir. Terazinin sol kefesine siyah bir kutu ve 50 gr ağırlık, sağ kefesine de 150 gr ağırlık konduğunda terazinin yine dengede olduğu görülür. Denge durumu resmettirilmek suretiyle tahtaya yazdırılır. Siyah kutu bilinmeyen olarak adlandırılarak dengenin matematiksel cümlesi yazdırılır. Terazinin sol kefesindeki siyah kutunun ağırlığını bulabilmek için kutu sol kefede yalnız bırakılmalıdır. Bunun için kutunun hemen yanında yer alan 50 gr'lık ağırlığın yok edilmesi gerekmektedir. Halen dengede bulunan terazinin dengesinin bozulmaması için sol kefeden alınan ağırlığın karşılığı olarak sağ kefeden de aynı ağırlık alınarak denge korunur. Bu uygulama matematik işlemine dönüştürülerek denklem çözülür. 


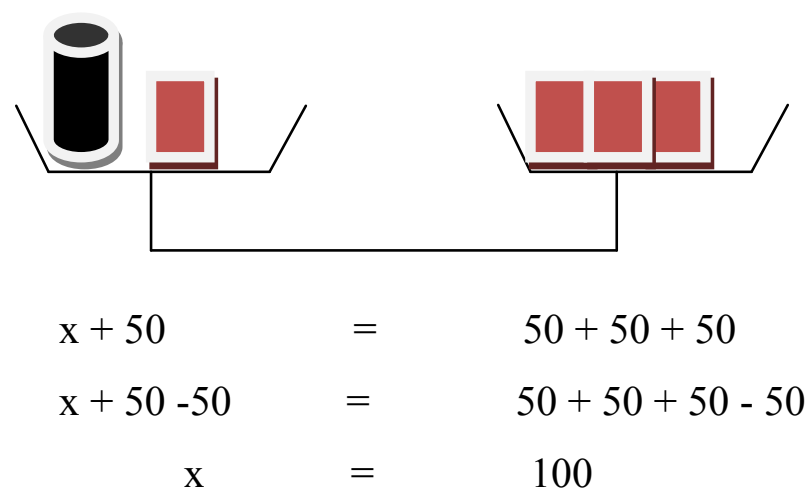

\section{Etkinlik 2}

$50 \mathrm{~cm}$ x $100 \mathrm{~cm}$ boyutlarında köpükten oluşturulan ve ikiye ayrılmış dikdörtgen pano bir teraziyi temsil etmektedir. Önceden oluşturduğumuz $5 \mathrm{~cm}$ x $5 \mathrm{~cm}$ ebatında mavi ve pembe sayma pullarından pembe olanlar $(+1)$ pozitif tam sayısına karşılık gelen 1 birim ağırlığı, mavi olanlar ise (-1) tamsayısına karşılık gelen 1 birim ağırlığı, sarı kalp ise bilinmeyeni temsil etmektedir. (Şekil 2)

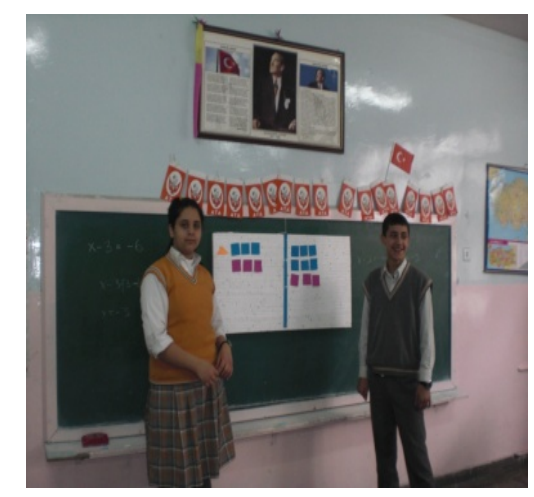

Şekil 2. Teraziyi Temsil Eden Dikdörtgen Pano
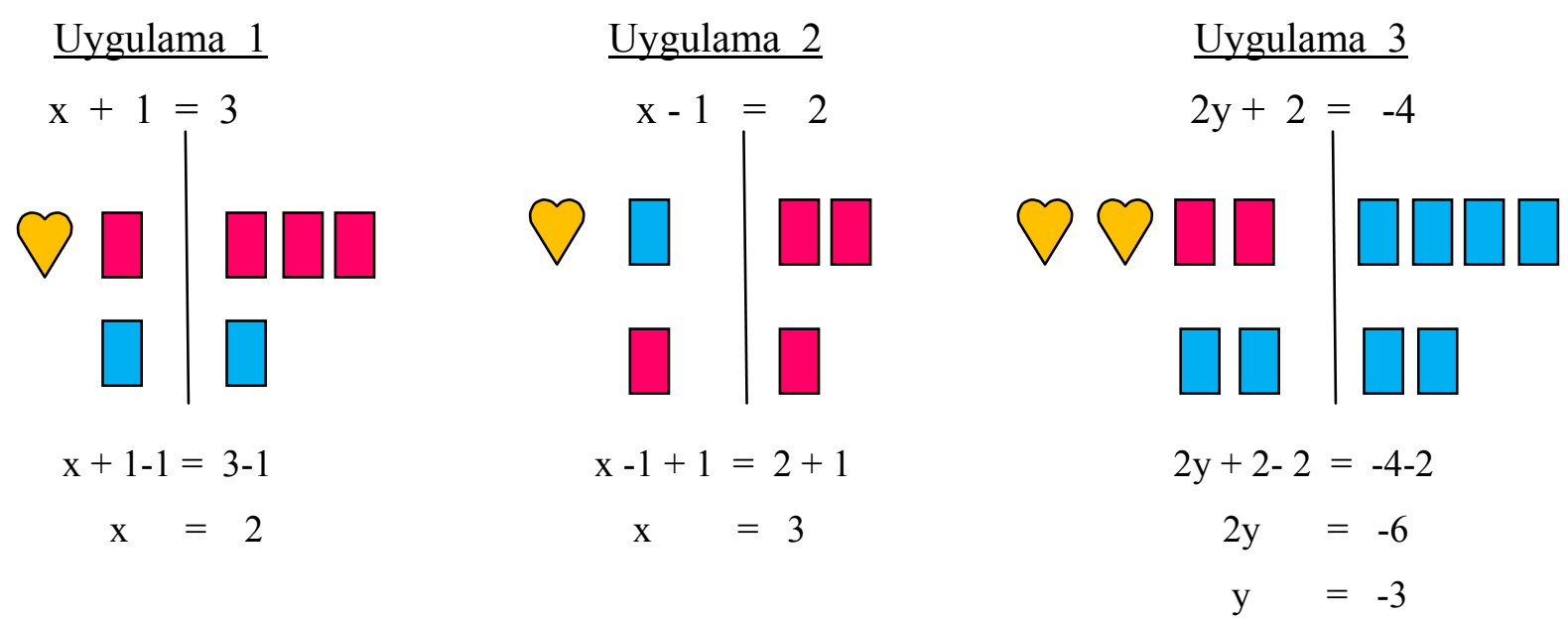

Uygulama 1'deki denklemin çözümünde eşitliğin korunumunu bozmamak için bilinmeyeni yalnız bırakmak amaç edinilmiş olduğundan eşitliğin her iki tarafına da ( -1$)$ tam 
sayısına karşılık gelen 1 birim ağırlık (mavi pul) eklersek denge bozulmaz. Eşitliğin sol tarafındaki pembe pul ile mavi pul kendi arasında 0 çifti oluşturup sadeleşirken geriye sarı kalp (x), să̆ tarafta da aynı şekilde pembe pul ile mavi pulun sadeleşmesinden geriye $(+2)$ tamsayısına karşılık gelen 2 pembe birim ağırlık kalır. Denklem çözüme kavuşmuş olur.

Uygulama 2'deki denklemin çözümünde bilinmeyeni yalnız bırakmak için dengede olan düzeneğin her iki tarafına da $(+1)$ tamsayısına karşılık gelen birer pembe pul eklenir. Sol tarafta pembe pul ile mavi pulun 0 çifti oluşturmasıyla sarı kalp (x) kalırken, sağ tarafta bir pembe pulun eklenmesiyle pembe pul sayısı 3'e çıkar.

Uygulama 3'te ise eşitliğin korunumu adına her iki tarafa da (-2) tamsayısına karşıllık gelen 2'şer mavi pul eklenerek bilinmeyenin yalnız kalması amaçlanır. Sol tarafta, 2 sarı kalp (2y) kalırken sağ tarafta mavi pul sayısı 6 ya çıkar. 2 kalp 6 mavi pula denk ise 1 kalp 3 mavi pula denk olur ki $\mathrm{y}=-3$ sonucuna ulaş1lır.

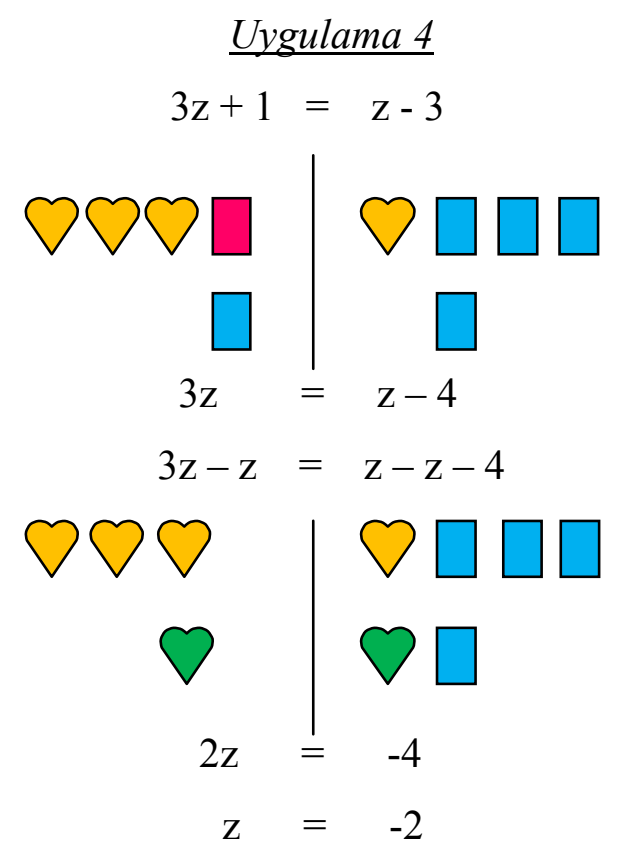

Uygulama 4'te ise denklemin her iki tarafında da bilinmeyenler görülmektedir. Amaç, bilinmeyenleri bir tarafa toplamak ve eşitliğin bozulmaması için her iki tarafa da birer mavi pul ekleyerek dengeyi korumaktır. Denklem, $3 z=z-4$ haline gelir. Sağ taraftaki bilinmeyeni yok etmek için her iki tarafa da sarı kalp (z) ile 0 çifti oluşturacak yeşil kalp (-z) eklenir. Bilinmeyenler kendi içinde sadeleşirken sol tarafta 2 z sağ tarafta ise -4 kalır, z'nin -2 olduğu sonucuna ulaşılır.

Bu örneklerden sonra, rasyonel katsayılı denklemler çözdürülür. 


\section{Etkinlik 3}

Sınıfa pembe, mavi, sarı renkte kartonlar ve makas getirilir. Sınıf sıra düzeninde 2 'şerli oturtulur. Her 2 kişi bir grup oluşturur. Gruptakiler pembe ve mavi kartonları $5 \mathrm{~cm} x$ $5 \mathrm{~cm}$ ebatında, sarı kartonu istedikleri bir bilinmeyen biçiminde keserler (Şekil 3). Öğretmen tahtaya denklemler yazar, öğrenciler 2'li gruplar halinde bu denklemleri çözerler. Burada dikkat edilmesi gereken, grup üyelerinin anlaşarak birlikte hareket etmelerinin sağlanmasıdır, 1. neyi yapıyorsa 2.nin de aynı aktiviteyi yapmasıdır. Etkinlik yarışma biçiminde düzenlenebilir. Denklemleri en kısa zamanda ellerindeki kartonlar yardımıyla çözüp, gösteren grup ödüllendirilebilir.

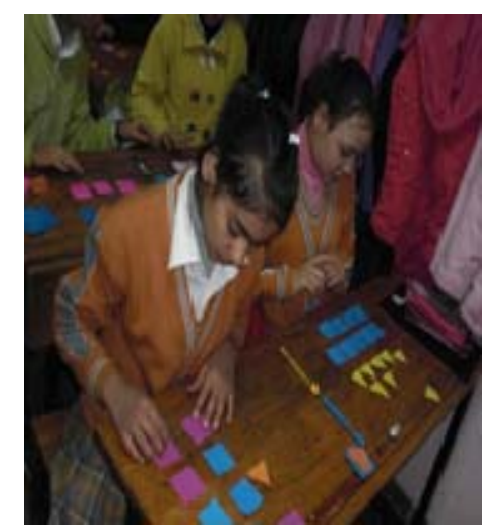

Şekil 3. Etkinlik 3’ü Uygulamaya Çalışan İki Öğrenci

\section{Etkinlik 4}

$\mathrm{Bu}$ etkinlikte denklemleri çözmeyi öğrenen öğrencilerin sözel problemleri denklemlere dönüştürerek bir çözüm yolu bulmaları amacıyla bir çalışma yaprağı hazırlanmştır. Çalışma yaprağının sol tarafında belirli sayılar kullanılarak oluşturulmuş problemler ile sağ tarafında yine aynı sayılar kullanılıp oluşturulmuş bu problemlerin çözümünü sağlayabilecek olan denklemlere yer verilmiş ve bunları doğru bir şekilde eşleştirmeleri, ardından denklemleri çözüp problemlerin sonuçlarına ulaşmaları istenmiştir. Sınıf 4 kişilik gruplara ayrılarak öğrencilerin işbirliği ve tartışma yapmaları sağlanmıştır.

İşlem

Araştırma kapsamında uygulamalara başlamadan önce, hazırlanan ölçme aracı ön test olarak gruplara uygulanmıştır. Gruplar test maddelerini boş bırakmamaları konusunda uyarılmışlardır.

Uygulamalar, deney grubunda uygulanacak etkinliğe bağlı olarak iki, üç ya da dört-beş kişilik gruplar halinde çalışma imkânı sağlanarak gerçekleştirilmiştir. Küçük gruplar halinde çalışma, hem gruptaki her bireyin sürece aktif katılımını mümkün kılmış, hem de işbirlikçi 
öğrenme yoluyla daha etkili ve kalıcı öğrenmelerin ortaya çıkması sağlanmıştır. Bu grupta öğrencilerin aktif olmasını gerektiren farklı tür etkinlikler tasarlanmış ve uygulanmıştır. $\mathrm{Bu}$ etkinliklerde, öğretmen süreci başlatan bir rehber rolünde olup, öğrenciler süreçte öğretim materyalleriyle bire bir iletişim kurmuş ve hayatla ilişkili materyaller konunun daha eğlenceli öğrenilmesine yardımcı olmuştur. Sınıfa götürülen terazi öğrencilerin konuya ilgilerini arttırmış ve bu aşamada öğretmen bir model olarak terazi yardımıyla bir denklemi formüle etmiştir. Daha sonra, öğrencilerden teraziyi kullanarak, farklı denklemler kurmaları istenmiştir. Kullanılan otantik materyallerin öğrencilerin derse ilgilerini çekmek ve öğrencinin bu materyaller arasındaki ilişkileri daha da somutlaştırmalarını sağlamak için, dersin bir aşamasında, öğrenciler ikili gruplara ayrılmış ve gruptaki her öğrencinin terazinin bir kefesi olması istenmiştir.

Öğrencilerden denklemi bizzat kendilerinin modellemeleri istenmiş ve denklemlerin bir tarafına yapılan işlemin diğer tarafına da yapılması gerekliliği herbiri bir kefeyi temsil eden iki öğrencinin aynı anda kefe üzerinde müdahalelerde bulunmaları vasıtasıyla sezdirilmiştir. $\mathrm{Bu}$ etkinlik, öğrencilerin somut materyaller üzerinde soyut formülleri modellemelerini kolaylaştırmış ve dersi hem öğretici hem de eğlenceli hale getirmiştir. Öğretmen bu süreci başlattıktan sonra, yorumlamaların, analiz ve süreç ile ilgili konuşmaların öğrenciler tarafından yapılmasını sağlamıştır. Sözel problemleri denklemlere dönüştürme etkinliğinde, öğrenciler dörtlü gruplara ayrılmış ve sol tarafta sözel problemler ve sağ tarafta ise bu problemlerin çözümü olabilecek denklem sistemlerini içeren çalışma yaprağ dağıtılmıştır. Öğrencilerden sağ taraftaki denklem sistemlerinden sözel problemlerin çözümü olabilecek denklemleri tartışmaları istenmiştir. Bu da geleneksel yaklaşımda pasif olan, bilgiyi alan, ezberleyen öğrenci rolünü değiştirmiş, sorgulayan, analiz eden, tartışan, akrandan öğrenenen ve bilgiyi kendi yapılandıran bir öğrenci profili ortaya çıkarmıştır.

Genel olarak bakıldığında, bazı etkinliklerde tüm sınıfın birlikte katılımı sağlanırken bazılarında ise etkinlikler gruplara dağıtılarak deney yapmaları ve yaptıkları deneylerle ilgili çalışma yaprağının ilgili yerlerini yazmaları sağlanmıştır. Etkinliklerin uygulanması sırasında grup çalışması, işbirlikli öğrenme, yaparak yaşayarak öğrenme, grup tartışması gibi yaklaşımlar kullanılmıştır. Uygulama süreci boyunca, öğrencilerin etkinlikler hakkında tartışmaları sağlanmıştır.

Kontrol grubunda ise dersler öğretmen merkezli olarak yürütülmüştür. Bu süreçte konu ders kitabındaki düzene bağlı olarak öğretmen tarafından sözlü olarak anlatılmış ve öğretmen anlattıklarına ilişkin gerekli notları tahtaya yazmıştır. Öğretmen notları tahtaya yazarken önemli gördüğü kısımları renkli tebeşirle çerçeve içine almıştır. Bu sınıfta genel anlamda 
öğrenciler sessiz ve hareketsiz bir şekilde yerlerinde oturdukları için sürece etkin katılmamışlardır. Öğretmen yazdığı notlarla tahtayı doldurduktan sonra öğrencilere tahtadaki notları defterlerine yazmaları için süre vermiştir. Bu süreçte öğretmen öğrencilere konuyla ilgili varsa sorular sormalarını istemiştir. Bu sırada, öğretmen sınıfta dolaşarak öğrencilerin sorularına cevap vermiştir. Ancak, tüm süreç boyunca belirli öğrenciler, öğretmenden izin alarak konuya ilişkin sorular sorabilmişlerdir. Kontrol grubunda bir ders saatinin yaklaşık \%70-75'i öğretmenin konuşmaları ile geçmiştir. Konu anlatımı bittikten sonra öğretmen öğrencilerden ünite sonundaki problemleri çözmelerini istemiştir. Bu süreçte derslerin yürütülmesi deney ve kontrol gruplarında dersin matematik öğretmeni tarafından 2010-2011 eğitim öğretim yılında müfredat programında belirtilen zamanda her bir sınıfta 16 ders saati uygulanmıştır. Uygulamalar birbirine yakın zaman aralıklarında gerçekleştirilmiştir. Her iki grupta da uygulamalar bittikten bir hafta sonra ölçme aracı son test olarak uygulanmıştır.

\section{Verilerin Analizi}

Uygulama sonucunda elde edilen veriler SPSS paket programı kullanılarak analiz edilmiştir. Çalışmada grupların kullanılan testten aldıkları puanların ortalama değerleri, standart sapmaları, gruplardaki toplam katılımcı sayıları ve gruplardaki kız ve erkek sayıları analiz edilmiştir. Veri analizinde, t-testi kullanılarak grupların ön test-son test ortalama puanları arasında anlamlı bir fark olup olmadığı belirlenmiştir. $\mathrm{Bu}$ analizler yapılırken, öğrencilerin ön ve son testte başarı puanları bulunurken, her soru için verdikleri doğru cevaplar 1, yanlış cevaplar için ise 0 olarak paket programa girilmiştir.

\section{Bulgular ve Yorumlar}

Tablo 1'de deney ve kontrol gruplarına ait ön-test sonuçları görülmektedir. Deney grubunun ön test puanlarına ait ortalaması ile kontrol grubunun ön test puanlarına ait ortalaması arasındaki fark, t-testiyle karşılaştırılmış $\mathrm{p}<.05$ düzeyinde anlamlı bir fark bulunmamıştır. $\mathrm{Bu}$ verilere göre araştırmanın başında deney ve kontrol gruplarının ön test puanları arasında anlamlı bir farkın olmadığı söylenebilir.

Tablo 1 Deney ve Kontrol Gruplarının Ön Test Puanları

\begin{tabular}{llllll}
\hline Gruplar & $\mathbf{n}$ & $\bar{X}$ & Ss & t & p \\
\hline Deney & 30 & 2,37 & 1,14 & 1,06 & \\
\hline Kontrol & 28 & 2,25 & 1,07 & & 0,987 \\
\hline
\end{tabular}


Tablo 2’te Deney ve Kontrol gruplarına ait son-test sonuçları görülmektedir. Deney grubunun son test puanlarına ait ortalamaları ile kontrol grubunun son test puanlarına ait ortalamaları arasındaki fark, t-testiyle karşılaştırılmış $\mathrm{p}<.05$ düzeyinde anlamlı bir fark bulunmuştur. $\mathrm{Bu}$ verilere dayanarak, deney ve kontrol gruplarının son test başarıları karşılaştırıldığında deney grubunun daha başarılı olduğu bulunmuştur.

Tablo 2 Deney ve Kontrol Gruplarının Son-Test Puanları

\begin{tabular}{llllll}
\hline Gruplar & $\mathbf{n}$ & $\bar{X}$ & Ss & T & p \\
\hline Deney & 30 & 5,27 & 0,91 & 1,46 & 0,006 \\
\hline Kontrol & 28 & 3,11 & 1,22 & & \\
\hline
\end{tabular}

Öğrencilerin 1. dereceden denklemler konusundaki problemlerini tespit etmek için geliştirilen cebir testinin ön ve son test sonuçlarının karşılaştırılması sonucunda deney ve kontrol gruplarındaki öğrencilerin hatalarını düzeltme oranları ortaya çıkmıştır.

Tablo 3'te deney grubundaki öğrencilerin, ön testte 1. dereceden denklem konusunda hem deney hem de kontrol gruplarında problem yaşayan ve soruları yanlış yapan öğrenci sayısı verilmiştir. Aynı şekilde, grupların ön test-son test oranlarını karşılaştırmak için soruları yanlış yapan öğrenci sayıları verilmiştir. Böylece, deney ve kontrol gruplarında son testte hataların giderilme yüzdeleri karşılaştırılmıştır.

Tablo 3 Deney Grubundaki Öğrencilerin Ön Testten Son Teste Hata Değiştirme Oranları

\begin{tabular}{|c|c|c|c|c|c|c|}
\hline \multirow[t]{6}{*}{ Soru } & \multicolumn{2}{|c|}{ Ön Test } & \multicolumn{2}{|c|}{ Son Test } & \multicolumn{2}{|c|}{ Hataların düzeltilme oranları } \\
\hline & \multirow{5}{*}{$\begin{array}{l}\text { Deney Grubu } \\
\text { Hata Yapan } \\
\text { Say1s1 } \\
(\mathrm{n}=30)\end{array}$} & \multirow{5}{*}{$\begin{array}{l}\text { Kontrol } \\
\text { Grubu Hata } \\
\text { Yapan } \\
\text { Say1s1 } \\
(\mathrm{n}=28)\end{array}$} & \multirow{5}{*}{$\begin{array}{l}\text { Deney } \\
\text { Grubu Hata } \\
\text { Yapan } \\
\text { Say1s1 } \\
(\mathrm{n}=30)\end{array}$} & \multirow{5}{*}{$\begin{array}{l}\text { Kontrol Grubu } \\
\text { Hata Yapan } \\
\text { Sayis1 } \\
(\mathrm{n}=28)\end{array}$} & & \\
\hline & & & & & & \\
\hline & & & & & & \\
\hline & & & & & & \\
\hline & & & & & Deney & Kontrol \\
\hline 1 & 26 & 23 & 21 & 22 & $\% 19.2$ & $\% 4.3$ \\
\hline 2 & 23 & 22 & 19 & 21 & $\% 17.4$ & $\% 4.5$ \\
\hline 3 & 28 & 25 & 25 & 24 & $\% 10.7$ & $\% 4$ \\
\hline 4 & 25 & 24 & 20 & 21 & $\% 20$ & $\% 12.5$ \\
\hline 5 & 25 & 24 & 7 & 19 & $\% 72$ & $\% 20.8$ \\
\hline 6 & 18 & 19 & 10 & 17 & $\% 44.4$ & $\% 10.5$ \\
\hline 7 & 18 & 18 & 5 & 16 & $\% 72.2$ & $\% 11.1$ \\
\hline 8 & 24 & 20 & 15 & 18 & $\% 37.5$ & $\% 10$ \\
\hline 9 & 14 & 16 & 8 & 13 & $\% 42.9$ & $\% 18.8$ \\
\hline 10 & 28 & 26 & 12 & 22 & $\% 57.14$ & $\% 15.4$ \\
\hline
\end{tabular}


Tablo 3 incelendiğinde, ön testte deney grubundaki 30 öğrencinin 26's1 1. soruya, 23'ü 2 .soruya, 28'i 3. soruya , 25'i 4. soruya, 25'i 5. soruya, 18'i 6. soruya, 18'i 7.soruya, 18 'i 8. soruya, 14'ü 9. soruya ve 28 'si 10. soruya yanlış cevap vermişlerdir. Aynı şekilde, kontrol grubundaki 28 öğrencinin 23'ü 1. soruya, 22'si 2.soruya, 25'i 3.soruya , 24'ü 4 . soruya, 24 'ü 5 . soruya, 19'ü 6 . soruya, 18 'i 7.soruya, 20'si 8. soruya, 16's1 9. soruya ve 26's1 10. soruya yanlış cevap vermişlerdir. Bu sonuçlar, deney ve kontrol grubundaki öğrencilerin 1. dereceden denklemler konusundaki ön bilgilerinin birbirine yakın olduğunu göstermektedir.

Tablo 3 incelendiğinde, deney grubuna etkinlik temelli bir yaklaşımla ve kontrol grubuna ise geleneksel bir yaklaşımla öğretim gerçekleştirildikten sonra her iki gruba uygulanan son testte, deney grubundaki 30 öğrencinin 21 'i 1 . soruya, 19'u 2. soruya, 25'i 3.soruya, 20'si 4. soruya, 7'si 5. soruya, 10'u 6. soruya, 5'i 7. soruya, 15'i 8. soruya, 8'i 9. soruya ve 12'si 10. soruya yanlış cevap vermişlerdir. Aynı test sonucuna göre, kontrol grubundaki 28 öğrencinin 22'si 1. soruya, 21'i 2.soruya, 24'ü 3.soruya, 21'i 4. soruya, 19'u 5. soruya, 17 'si 6 . soruya, 16'si 7.soruya, 18'i 8. soruya, 13'ü 9. soruya ve 22 'si 10 . soruya yanlış cevap vermişlerdir.

Aynı tabloya göre, hem deney grubu, hem de kontrol grubundaki öğrencilerin sontestte hatalarını düzeltme oranları karşılaştırıldığında, deney grubundaki öğrencilerin 1. soruda hatalarını düzeltme oranları \% 19.2 iken, kontrol grubunda bu oranın \% 4.3 olduğu, deney grubundaki öğrencilerin 2. soruda hatalarını düzeltme oranları \% 17.4 iken, kontrol grubunda bu oranın \% 4.5 olduğu, deney grubundaki öğrencilerin 3. soruda hatalarını düzeltme oranları \% 10.7 iken, kontrol grubunda bu oranın \% 4 olduğu, deney grubundaki öğrencilerin 4. soruda hatalarını düzeltme oranları \% 20 iken, kontrol grubunda bu oranın \% 12.5 olduğu, deney grubundaki öğrencilerin 5. soruda hatalarını düzeltme oranları \% 72 iken, kontrol grubunda bu oranın \% 20.8 olduğu, deney grubundaki öğrencilerin 6. soruda hatalarını düzeltme oranları \% $44.4 \mathrm{iken,} \mathrm{kontrol} \mathrm{grubunda} \mathrm{bu} \mathrm{oranın} \mathrm{\%} 10.5$ olduğu, deney grubundaki öğrencilerin 7. soruda hatalarını düzeltme oranları \% $72.2 \mathrm{iken}$, kontrol grubunda bu oranın \% 11.1 olduğu, deney grubundaki öğrencilerin 8. soruda hatalarını düzeltme oranları \% 37.5 iken, kontrol grubunda bu oranın \% 10 olduğu, deney grubundaki öğrencilerin 9. soruda hatalarını düzeltme oranları \% 42.9 iken, kontrol grubunda bu oranın \% 18.8 olduğu, deney grubundaki öğrencilerin 10 . soruda hatalarını düzeltme oranları $\% 57.14$ iken, kontrol grubunda bu oranın \% 15.4 olduğu görülmektedir. Bulgular etkinlik temelli eğitimin geleneksel eğitime oranla daha olumlu sonuçlar verdiğini göstermektedir. Bu bulgu, Özlü (2001)'nün öğrencilerin daha aktif tutulduğu sınıf ortamlarında öğrenci başarı ve 
tutumlarının daha yüksek olduğu bulgusuyla paralellik göstermektedir. $\mathrm{Bu}$ çalışma, etkinliklerin öğrencilerin cebirsel ifadeleri anlamalarına yardımcı olduğunu göstermektedir.

Araştırma sürecinde ön-test öğrencilere uygulandığında, öğrencilerin çoğunun problemleri aritmetiksel yolla çözmeye çalıştı̆̆ gözlemlenmiştir. Oysaki ülkemizdeki ilköğretim matematik müfredatında formal olarak bilinmeyen kavramı ve bilinmeyenleri içeren işlemlerin kullanımı 6. sınıftan itibaren gösterilmektedir (MEB 2009). Bu durum, 7. sınıf öğrencilerinin ilköğretim birinci kademedeki aritmetiksel işlem yapma alışkanlıklarını sürdürdüğünü ve 6 . sinıfta gördükleri bilinmeyen içeren işlemleri kullanmayı halen içselleştiremediklerini ortaya koymaktadır. Benzer şekilde, Akkan (2009), yaptığı çalışmada 7. sınıf öğrencilerinin aritmetik özellikleri içeren çözümlerinin yüksek yüzde değerine sahip olmasını düşündürücü bulmuştur. Bulgular sonucunda, bazı öğrencilerin problemlerin çözümünde aritmetik stratejileri tercih etmede 1srar ettikleri görülmüştür. $\mathrm{Bu}$ durum, öğrencilerin cebirdeki bilinmeyen kavramını bir belirsizlik olarak gördüklerinden, bilinmeyen veya değişken kavramını kullanmadaki yetersizliklerden veya sözel problemleri denklemlere dönüştürememekten kaynaklanıyor olabilir. Aynı şekilde, Kieran (1992), Linchevski ve Hersovics (1996) ilköğretim 1. kademe öğrencilerinin problem çözümlerinin genel olarak aritmetik özellikler içerdiğini belirtmişlerdir.

Elde edilen bulgulardan, öğrencilerin ön-testten son-teste gelişimlerinde, bu öğrencilerin aritmetikten cebire geçişini kolaylaştıran cebir öncesi (aritmetik cebir arası) özellikleri içeren çözümleri kullanmalarının payı olduğu söylenebilir. Benzer şekilde, Linchevski (1995) de 7. sınıf öğrencilerinin bu çözüm stratejilerini kullandıklarını dile getirmektedir. Akkan (2009), aynı paralelde bulgular elde etmiştir.

Etkinlik temelli öğretimde, öğrenciler derse aktif katılım göstermiş, birbirleri ve öğretmenleriyle etkinlikler vasıtasıyla sürekli etkileşimde bulunmuşlardır. Bu tür yaklaşımlar, öğrencinin ilgisini aktif tutması, soyut olan matematiği somutlaştırması, öğrencilerin matematiğin gerçek hayatta yansımalarının ve kullanım alanlarının olduğu fikrini benimsemelerini sağlaması açısından büyük önem taşımaktadır. Öğretmen açısından daha fazla ön hazırlık ve araştırma gerektirse de, etkinlik temelli öğretim ülkemizde çoğu öğrencinin kabusu olan matematiğin öğrenciler tarafından sevilmesi ve öğrenilmesi bakımından önemlidir. Yapılan bu araştırmada, etkinlik temelli öğretimin akademik başarıyı arttırdığı ortaya çıkmıştır. Ayrıca, sınıf içi katılımı ve öğretmenin derse hakimiyetini de arttırmıştır. Öğretmenin derse hakimiyeti için bir ölçek geliştirilmemiş olmakla beraber klasik öğretim metotlarıyla pasifize olan öğrencilerin dersten kopması ve kendine başka uğraşlar edinmesi ihtimali etkinlikler yoluyla öğrencinin aktif rol üstlenerek, eğitim-öğretim sürecine 
paydaş edilmesiyle ortadan kaldırılmaya çalışılmıştır. Araştırmacılardan biri aynı zamanda dersi yürüten öğretmen olduğundan derse hakimiyetinin arttığını yaptığı gözlemlerle de doğrulamıştır.

Matematik dersinde 1. dereceden denklemler konusunu öğretme yaklaşımı değiştirilerek, belli bir süre farklı yaklaşımlar uygulanan bu iki grubun son testten sonra öğrenim çıktılarının farklılaştığı görülmektedir. Kontrol grubunda en yüksek \% 20.8, en düşük \% 4 oranlarında hata düzeltmeleri görülürken, deney grubunda en yüksek $\% 72.2$, en düşük \% 10.7 oranlarında hata düzeltmeleri ortaya çıkmıştır. Gürbüz (2010); Arı, Çavuş ve Sağlık (2010) ve Sağlık (2007) aynı şekilde, etkinlik temelli öğretim yaklaşımının, öğrenci başarısı ve kalıcılığını genelde arttırdığını ortaya koymuşlardır.

Etkinlik temelli öğretim yaklaşımının, geleneksel öğretim yaklaşımına oranla öğrencilerin 1. dereceden denklemleri kavramalarında daha etkili olduğu söylenebilir. Etkinlik temelli öğretimin, öğrencilerin akademik çıktılarını daha fazla zenginleştirdiği ifade edilebilir.

\section{Sonuç, Tartışma ve Öneriler}

$\mathrm{Bu}$ çalışma, etkinlik temelli matematik öğretiminin, öğrencilerin 1. dereceden denklemleri kavramalarına yardımcı olduğunu ve bu tür bir öğretimin öğrencilerin aritmetikten cebire geçiş süreçlerini kolaylaştırdığını göstermektedir. Ayrıca, etkinlik temelli matematik öğretiminin, süreci daha eğlenceli kıldığı, matematiğe olan ilgiyi arttırdığı ve aritmetikten cebire geçiş sürecini hızlandırdığı söylenebilir. Bu çalışma, Akkan (2009)'ın öğrencilerin problem çözme, ak1l yürütme, iletişim, ilişkilendirme becerilerinin kazandırılması ve sistemli, sabırlı, dikkatli ve sorumluluk sahibi olma özelliklerinin etkinlik temelli öğretimle geliştirildiğini ortaya koyduğu çalışmasının bulgularıyla paralellik göstermektedir. $\mathrm{Bu}$ çalışma, ayrıca öğrencilerin matematiği yaşayarak öğrenebilecekleri etkinliklerin aritmetikten cebire geçiş sürecinde işe koşulmasının önemini ortaya koymaktadır. Çıkla (2008) öğretmenlerin, öğrencilere cebiri kullanabilecekleri ortamlar oluşturarak öğrencilerin aritmetik işlemleri cebirsel işlemlere tercih etme eğilimlerini ortadan kaldırabileceklerini belirterek benzer bulgular elde etmiştir.

Türkiye'de 2005'te uygulamaya başlanan yapılandırmacı yaklaşım, etkinlik temelli matematik öğretimini desteklemektedir. B1kmaz (2006), bu girişimin öğrencilerin düşünceleri ve kavramsallaştırmaları üzerinde önemle duran, etkinlik temeline dayanan, ortaya konan üründen çok öğrenme sürecinin vurgulandığı, kavramları ve temaları düşünme becerilerini 
geliştirmek için bir araç olarak kullanan ve dolayısıyla bireysel gelişim üzerinde odaklanan önemli bir girişim olduğunu dile getirirken aslında etkinlik temelli eğitimin, eğitim sistemimizdeki öğrenme ve öğretme kavramlarının bütünüyle değiştirebilecek bir süreç olduğunu vurgulamaktadır. $\mathrm{Bu}$ çalışma, yapılandırmacı yaklaşımın temelleri olan, öğrencilerin yaparak yaşayarak öğrenmesi, sınıf içinde öğrencinin aktif olduğu problem çözme süreçleri, öğrencilerin bilgiyi depolayan değil, bilgiyi yaşayarak üretmesi gibi yaklaşımları destekler nitelikte bulgular ortaya koymuştur. Bu bakımdan, etkinlik temelli yaklaşıma dayanan, yapılandırmacı yaklaşımın öğrenme süreçlerinde katma değer yarattığı sonucunu da ortaya koymuştur.

Etkinlik temelli matematik öğretiminin etkililiği için, etkinliklerin tasarlanması, uygulanması safhalarında öğretmen eğitiminin çok önemli olduğu bilinmektedir. Öğretmenlerin etkinlik kavramıyla ilgili genel olarak kısıtlı bir algıları olduğunu, etkili bir etkinlik temelli öğretim için öğretmen eğitiminin önemli olduğu (Özmantar, vd. 2010) düşünüldüğünde, Türkiye'de bu sürecin etkili olarak çalışması için tüm kaynakların ortaya konması ve öğrenci öğrenmesinde olumlu değişiklikler yapan her yaklaşımın desteklenmesi gerekmektedir. Bununla beraber, ortaöğretim seviyesinde daha da soyutlaşan matematik öğretiminin etkinlik temelli tasarlanması ile ilgili çalışmalar yapılabilir. $\mathrm{Bu}$ çalışma denklemlerin etkinlik temelli öğretilmesinin etkililiğini ortaya koymuştur. Farklı matematik konularının öğretiminde de etkinlik temelli öğretimin etkisi araştırılabilir. Ayrıca etkinliklerin tasarlanması sürecine öğrencilerin aktif katılımı sağlanabilir. Nicel olarak yürütülen bu çalışmanın bulgularını destekleyecek nitel veri toplama araçları da işe koşulabilir.

Son olarak etkinlik temelli öğretimin, öğretmene derse hazırlık sürecine daha fazla zaman ayırma zorunluluğu getirdiği için olumsuz görülebilecek bir yanı olsa da, uzun süreçte öğrencilerin cebire geçiş süreçlerini kolaylaştıran ve matematiğin daha doğal bir ortamda öğrenilmesini mümkün kılan özelliklere sahip olduğu söylenebilir.

\section{Kaynakça}

Ainsworth, S. (2006). Deft: A conceptual framework for considering learning with multiple representations. Learning and Instruction, 16 (3), 183-198.

Ainley, J., Pratt, D. \& Hansen, A. (2006). Connecting engagement and focus in pedagogic task design, British Educational Research Journal, 32(1), 21-36.

Akar, F., 2006. Buluş yoluyla öğrenmenin ilköğretim ikinci kademe matematik dersinde ögrencilerin akademik başarılarına etkisi. Yüksek Lisans Tezi, Çukurova Üniversitesi Sosyal Bilimler Enstitüsü, Adana. 
Akgün, L. (2006). Cebir ve değişken kavramı üzerine, Journal of Qafqaz University, 17.

Akkan, Y. (2009). İlköğretim öğrencilerinin aritmetikten cebire geçiş süreçlerinin incelenmesi. Doktora tezi, Karadeniz Teknik Üniversitesi, Fen Bilimleri Enstitüsü.

Akkan, Y., Baki, A., Çakıroğlu, Ü. (2012). 5-8. Sınıf öğrencilerinin aritmetikten cebire geçiş süreçlerinin problem çözme bağlamında incelenmesi. Hacettepe Üniversitesi Ĕ̆itim Fakültesi Dergisi, 43,01-13.

Akkan, Y., Baki, A., Çakıroğlu, Ü. (2011). Aritmetik ile cebir arasındaki farklılıklar: Cebir öncesinin önemi. İlkögrretim Online, 10(3), 812-823.

Arı, K. Çavuş, H. ve Sağlık, N. (2010). İlköğretim 6. sınıflarda geometrik kavramların öğretiminde etkinlik temelli öğrenimin öğrenci başarısına etkisi. Pamukkale Üniversitesi Ĕ̈itim Fakültesi Dergisi, 27, 99-112.

Arcavi, A. ve Schoenfeld, A.(1988). On the meaning of variable. Mathematics Teacher, 81, 420-427.

Aygün, S.Ç., Aynur, N., Coşkuntürk, N., Çuha, S.S., Karaman, U., Özçelik, U., Ulubay, M., Ünsal, N. (2011). MEB 8. Sinıf matematik ögretmen kılavuz kitabı, MEB Yayınları, 4. Bask1, Ankara.

Bıkmaz, F. H. (2006). Yeni ilköğretim programları ve öğretmenler. Ankara Üniversitesi Ĕ̈itim Bilimleri Fakültesi Dergisi, 39 (1), 99-116.

Bingölbali, E.\& Özmantar, M.F.(2012). Ilköğretimde Karşılaşılan Matematiksel Zorluklar ve Çözüm Önerileri. Ankara: Pegem Akademi Yayınları.

Bernardo, A. \& Okagaki, L. (1994). Roles of symbolic knowledge and problem-information context in solving word problems. Journal of Educational Psychology, 86, 212-220.

Booth, L. (1988). Children's difficulties in beginning algebra. In A. F. Coxford (Eds.). The ideas of algebra, K-12 (pp. 20-32). Reston, VA: NCTM.

Cortes, A. ve Pfaff, N. (2000). Solving equations and inequations: operational invariants and methods constructed by students. Proceedings of the 24th Conference of the International Group for the Psychology of Mathematics Education, Hiroshima, Japan, 2, $193-200$.

Cüce, A.P. (2012). Etkinlik temelli matematik öğretimi yapılan sınıf ortamından yansımalar: Aksiyon araştırması. Yüksek Lisans Tezi, Karadeniz Teknik Üniversitesi, Eğitim Bilimleri Enstitüsü.

Çıkla, O.A. (2008). İki kare farkı. (Slavit, D., 1998) çalışmasından derleme. http://mategt.web.ibu.edu.tr/makaleler/IstatistikAtesi.htm 
Dede, Y., Yalın, H., A. ve Argün, Z. (2002). İlköğretim 8. sinif öğrencilerinin değişken kavramının öğrenimindeki hataları ve kavram yanılgıları, V. Ulusal Fen ve Matematik Eğitimi Kongresi, ODTÜ, Ankara.

Dede, Y. (2005). Birinci dereceden denklemlerin yorumlanması: Eğitim fakütlesi birinci sınıf öğrencileri üzerine bir çalışma. Cumhuriyet Üniversitesi Sosyal Bilimler Dergisi, 29(2), 197-205.

Dede, Y. \& Peker, M. (2007). Öğrencilerin cebire yönelik hata ve yanlış anlamaları: Matematik öğretmen adaylarının bunları tahmin becerileri ve çözüm önerileri, Ilkögretim Online, 6, 1, 35-49.

Doyle, W. (1988). Work in mathematics classes: The context of students' thinking during instruction. Educational Psychologist, 23, 167-180.

Dündar, S. \& Şenol. A. (2011). İlköğretim matematik dersi öğretim programında etkinliklerin tasarımı ile ilgili öğretmen görüşleri. I. Uluslararası Ĕ̆itim Programları ve Öğretim Kongresi. 05-08 Ekim, Anadolu Üniversitesi.

Falkner, K., Levi, L. \& Carpenter, T. (1999). Children's understanding of equality: A foundation for algebra. Teaching children mathematics, 6(4), 232-236.

Filloy, E. \& Rojano, T. (1989). Solving equations: The transition from arithmetic to algebra. For the Learning of Mathematics, 9(2), 19-25.

Güngör, S. (2005). Ortaöğretim geometri dersi üçgenler konusunda oluşturmacı yaklaşıma dayalı elle yapılan materyaller ve portfolyo hazırlamanın öğrenciler üzerindeki etkilerinin incelenmesi. Yüksek Lisans Tezi, Zonguldak Karaelmas Üniversitesi, Sosyal Bilimler Enstitüsü.

Gürbüz, R. (2008). Matematik ögrretiminde çoklu zekâ kuramına göre tasarlanan öğrenme ortamlarından yansımalar. Doktora Tezi, Karadeniz Teknik Üniversitesi, Fen Bilimleri Enstitüsü.

Gürbüz, R., Çatlığlu, H., Birgin, O.,\& Erdem, E. (2010). Etkinlik temelli öğretimin 5. Sınıf öğrencilerinin bazı olasılık kavramlarındaki gelişimlerine etkisi: Yarı deneysel bir çalışma. Kuram ve Uygulamada Eğitim Bilimleri, 10(2), 1021-1069.

Gürbüz, R. \& Akkan, Y. (2008). Farklı öğrenim seviyesindeki öğrencilerin aritmetikten cebire geçiş düzeylerinin karşılaştırılması: Denklem örneği. Eğitim ve Bilim, 33 (148), 64-76.

Healy, L, Fernandes,S. H. A. A., Frant, J. B. (2013). Designing tasks for a more inclusive school mathematics. In Margolinas, C. (Ed.). Task Design in Mathematics Education. Oxford. 
Herscovics, N \&Kieran, C. (1980). Constructing meaning for the concept of equation. Mathematics Teacher. 73 (8), 572-580.

Herscovics, N. ve Linchevski, L. (1994). Cognitive gap between arithmetic and algebra. Educational Studies in Mathematics, 27, 59 - 78.

Kerpiç, A., Bozkurt, A. (2011). Etkinlik tasarım ve uygulama prensipleri çerçevesinde 7. Sınıf matematik ders kitabı etkinliklerinin değerlendirilmesi. Mustafa Kemal Üniversitesi Sosyal Bilimler Enstitüsü Dergisi. 8(16), 303-318.

Kieran, C. (1989). The Early Learning of Algebra: A Structural Perspective. In S. Wagner \& C. Kieran (Eds.). Research Issues in the Learning and Teaching of Algebra, 3356. Reston, VA: NCTM.

Kieran, C. (1991). A procedural-structural perspective on algebra research. Proceedings of Fifteenth International Conference for the Psyschology of Mathematics Education, 2, 245-253.

Kieran, C. (1992). Handbook of research on mathematics teaching and learning. New York: Macmillan.

Kieran, C. \& Chaloug, L. (1993). Prealgebra: The transitions from arithmetic to algebra. In D.T. Owens (Eds.). Research Ideas for the Classroom: Middle Grades Mathematics, (pp. 179-198). New York: Macmillan.

Lee, F. (2002). Diagnosing students' algebra errors on the web. Proceedings of the International Conference on Computers in Education (ICCE'02).

Linchevski, L. (1995) Algebra with numbers and arithmetic with letters: A definition of prealgebra. The Journal of Mathematical Behaviour, 14, 113-120.

Linchevski, L. \& Herscovics, N. (1996). Crossing the cognitive gap between arithmetic and algebra: Operating on the unknown in the context of equations. Educational Studies in Mathematics, 30, 38-65.

Londholz, R., D. (1993). The transition from arithmetic to algebra. In E.L. Edwards (Ed), Algebra for everyone (pp. 24-33). Reston, VA: NCTM.

Macgregor, M. ve Stacey, K. (1997). Students' Understanding Of Algebraic Notation: 1115, Educational Studies in Mathematics, 33, 1-19.

MEB (2009). Illköğretim matematik dersi 6-8.sinıflar öğretim program ve kılavuzu. Ankara.

Memnun, D.S. (2008). Sekizinci sınıfta permütasyon ve olasılık konularının aktif öğrenme ile öğretiminin uygulama düzeyi öğrenci başarısına etkisi, Uludă̆ Üniversitesi Ĕ̆itim Fakültesi Dergisi, 21(2), 403-426. 
National Council of Teachers of Mathematics. (1989). Principles and Standards for School Mathematics, Reston.

Özlü, Ö. (2001). Ortaöğretim ögrrencilerinin matematiğe karşı tutumları. Yayınlanmamış Yüksek Lisans Tezi, Marmara Üniversitesi, İstanbul.

Özgenç, N. (2010). Oyun temelli matematik etkinlikleriyle yürütülen ögrrenme ortamlarından yansımalar.mYüksek Lisans Tezi, Karadeniz Teknik Üniversitesi, Fen Bilimleri Enstitüsü.

Özmantar, F., Bozkurt, A., Demir, S., Bingölbali, E. ve Açıl, E. (2010). Sınıf öğretmenlerinin etkinlik kavramina ilişkin algıları. Selçuk Üniversitesi, Ahmet Keleşoğlu Eğitim Fakültesi Dergisi, 30, 379-398.

Sağlık, N. (2007). Pilot uygulamaları yürütülen ilköğretim matematik programına yönelik etkinliklerin bazı geometri konularının öğretimi üzerindeki etkileri. Yüksek lisans tezi, YYÜ, Fen Bilimleri Enstitüsü, Van.

Suydam, M. \& Higgins, J. (1977). Activity-based learning in elementary school mathematics: recommendations from research. Columbus, OH: ERIC Clearinghouse for Science, Mathematics, and Environmental Education.

Tunç, M. P., Durmuş, S. \& Akkaya, R. (2012). İlköğretim Matematik Öğretmen Adaylarının Matematik Öğretiminde Somut Materyalleri ve Sanal Öğrenme Nesnelerini Kullanma Yeterlikleri.(http://dergi.matder.org.tr/dergiler/sayi1/2piskin tunc.pdf $\operatorname{adl}_{1}$ siteden 11.11.2012 tarihinde alınmıştır).

Tytler, R. (2003). A window for a purpose: Developing a framework for describing effective science teaching and learning. Research in Science Education, 33, 273-298.

Ursini, S. \& Trigerous, M. (2001). A model for the uses of variable in elementary algebra. Proceedings of the XXV PME International Conference. Utrecht, Neatherlands. (pp. 327-334).

Usiskin, Z. (1988). Conceptions of school algebra and uses of variables. In B. Moses (Eds.). Algebraic Thinking Grades, (pp. 7-14). Reston, VA: NCTM.

Van Amerom, B., A. (2002). Reinvention of early algebra: Developmental research on the transition from arithmetic to algebra. Unpublished doctoral dissertation, University of Utrecht, The Netherlands (http://igitur-archive.library.uu.nl/dissertations/2002-1105161148/full.pdf).

Van Doren, W., Verschaffel, L. ve Onghena, P. (2003). Pre-service teachers' preferred strategies for solving arithmetic and algebra word problems. Journal of Mathematics Teacher Education, 6, 27-52. 
Vlasis, J. (2004). Making sense of the minus sign or becoming flexible in 'negativity'. Learning and Instruction, 14, 469-484.

Yanpar, T. (2001). Illköğretim sosyal bilgiler dersinde oluşturmacı (constructivist) yaklaşımının ögrenciler üzerindeki çok yönlü etkilerinin niteliksel ve niceliksel olarak incelenmesi, (Doktora Sonrası Yapılan Yayınlanmamış Bağımsız Bir Araştırma Raporu), Zonguldak Karaelmas Üniversitesi, Zonguldak.

Yaşar, Ş., 1998. Yapısalcı Kuram ve Öğrenme-Öğretme Süreci, Anadolu Üniversitesi Ĕ̆itim Fakültesi Dergisi, 8(1-2), 68-75. 